\title{
Ötekiler ve uyanış: Ömer Seyfettin'in Ashab-ı Kehfimiz Hikâyesi ve E. M. Forster'in A Passage to India Romanı
}

\section{Abdullah Nejat TÖNGÜR'1}

\begin{abstract}
APA: Töngür, A. N. (2020). Ötekiler ve uyanış: Ömer Seyfettin’in Ashab-ı Kehfimiz Hikâyesi ve E. M. Forster'ın A Passage to India Romanı. RumeliDE Dil ve Edebiyat Araştırmaları Dergisi, (Ö7), 253-263. DOI: 10.29000/rumelide.808690.
\end{abstract}

\section{$\ddot{O} \mathbf{z}$}

E. M. Forster'ın A Passage to India (1924) ve Ömer Seyfettin's Ashab-ı Kehfimiz (1918) adlı eserleri 20.yüzyılın ilk çeyreğinde, o zaman İngiliz İmparatorluğunun bir sömürgesi olan Hindistan'ın Çandapur isimli hayalî bir şehrindeki ve Osmanlı İmparatorluğunun başkenti İstanbul'daki siyaset, toplum, kültür ve hayatı yansıtmakla beraber farklı milletlere, etnik kaynaklara, irklara, dillere ve dinlere mensup insanlar arasındaki ilişkilere de ışı tutar. Bu çalışmanın amacı bu iki eseri konuları ve olay örgüsü itibari ile karşılaştırmak ve benzerliklerini ortaya koymaktır. Aynı zamanda çalışmaya konu olan eserlerin olay örgülerinin geçtiği, çok milletli, çok kültürlü, çok dilli ve çok dinli devletler olan Osmanlı İmparatorluğunun ve İngiliz İmparatorluğunun coğrafi, sosyal, kültürel, etnik, dilsel ve dini farklılıkları da dikkate alınmaktadır. Ayrıca emperyalizm, sömürgecilik, milli kimlik ve ötekileştirme bağlamında bu iki eser incelenerek Hindistan'daki önemli mevkileri işgal eden ve İngiliz-Hint Kulübünün hayatlarının merkezine koyan az sayıdaki sömürge idarecisinin kendi ülkelerinde ırkçılı̆̆ına, aşağılamalarına ve 'ötekileştirmelerine' katlanmak zorunda kalan Hintliler ile halâ Osmanlı İmparatorluğu egemenliğinde yaşamakta olan Osmanlı Kaynaşma Kulübüne üyesi olan değişik milletlerin mensupları tarafından ve bazı Türkler tarafından kendi ülkelerinde 'öteki' muamelesi gören Türklerin durumu da araştırılmaktadır. Bu

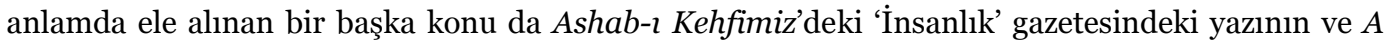
Passage to India'da Aziz'in yargılanmasının Türkleri ve Hintlileri içinde bulundukları duruma nihayet itiraz ettiren ve isyan ettiren olaylar olduğu savıyla bu olayların gelişim sürecini ve Ömer Seyfettin'in ve E. M. Forster'ın bu olaylara yaklaşımını ortaya koymaktır.

Anahtar kelimeler: Öteki, E. M. Forster, A Passage to India, Ömer Seyfettin, Ashab-ı Kehfimiz

\section{Others and awakening: Ömer Seyfettin's Ashab-ı Kehfimiz and E. M. Forster's A Passage to India}

\begin{abstract}
E. M. Forster's A Passage to India (1924) and Omer Seyfettin's Ashab-ı Kehfimiz (1918) reflect the politics, society, culture and life and shed light upon the relationships between people of different nationalities, ethnicities, races, religions, languages and cultures in Chandapore, a fictional city in colonial India and Istanbul, the capital city of the Ottoman Empire in the first quarter of the 2oth century. The aim of the study is to compare and show the similarities of the works as for the themes covered and their plots in spite of the geographical, social, cultural, ethnical, linguistic and religious differences of the multinational, multicultural, multi-language and multi-religious Ottoman Empire and British Empire where the plots unfold. Besides, Indians who are subjected to racism,
\end{abstract}

Dr. Öğr. Üyesi, Maltepe Üniversitesi, Eğitim Fakültesi, İngilizce Öğretmenliği (İstanbul, Türkiye), nejattongur@maltepe.edu.tr, ORCID ID: oooo-0002-1204-4399 [Makale kayıt tarihi: 17.07.2020-kabul tarihi: 20.10.2020; DOI: 10.29000/rumelide.808690] 


\begin{abstract}
humiliation and othering by a few colonial officials who man the prominent posts in India and who put the Anglo-Indian Club in the center of their lives as well as the Turks who are treated as the other in their own land by the people of different nationalities and some Turks from the Ottoman Merging Club (Osmanlı Kaynaşma Kulübü) will be within the scope of the study with an analysis of the works within the context of imperialism, colonialism, national identity and othering. With the assumption that the article in the newspaper, 'Humanity' (Insanlık) in Ashab-ı Kehfimiz' , and the trial of Aziz in A Passage to India are the events which led the Turks and the Indians to protest and to rebel, another relevant concern of the study is to describe the events and Ömer Seyfettin's and E. M. Forster's attitude to those events.
\end{abstract}

Keywords: The other, E. M. Forster, A Passage to India, Ömer Seyfettin, Ashab-ı Kehfimiz

\title{
Giriş
}

"Millî Edebiyat" akımının önemli yazarlarından biri olan Ömer Seyfettin (1884-1920) çok genç yaşta vefat etmesine rağmen önce Balkan Savaşında savaşmış ve esir düşmüş bir subay olarak sonra da yazar ve öğretmen olarak Osmanlı İmparatorluğunun son dönemlerine tanıklık etmiştir. Milliyetçi duygular ile bezenmiş Efruz Bey, Yalnzz Efe, Harem, Yüksek Ökçeler, Gizli Mabed, Beyaz Lale, Asilzâdeler, İlk Düşen Ak, Mahçupluk İmtihanı, Yarınki Turan Devleti ve Türklük Mefkûresi gibi çok sayıda eseri Türk edebiyatına kazandırmış ve pek çok eseri ölümünden sonra ve tekrar basılmıştır. Özellikle Başını Vermeyen Şehit, Kütük, Pembe İncili Kaftan, Bomba, Beyaz Lale, Nakarat, Hürriyet Bayraklarl, Çanakkale'den Sonra, Mefkûre, Aleko Bir Çocuk, Kaç Yerinden, Primo Türk Çocuğu, Kaşağı ve Falaka gibi hikâyelerinde Türklük bilinci, Türkçenin önemi ile Osmanlı Devleti’nin siyasi durumuna ve sorunlarına ilişkin farkındalık oluşturma çabası özel yer tutar. İngiliz yazar Edward Morgan Forster (1879-1970) ise Where Angels Fear to Tread (Meleklerin Uğramadığı Yer), The Longest Journey, A Room with a View (Manzaralı Bir Oda), Howards End ve ölümünden sonra basılan Maurice adlı romanlarının yanı sıra hikâyeleri, mektupları, makaleleri ve seyahat yazıları ile bilinen ve İngiliz Edebiyatının en çok okunan ve çalışılan yazarlarından biri olup eserlerinden bazıları Türkçeye çevrilmiştir. Forster da I. Dünya Savaşında ve sonrasında İskenderiye-Mısır'da Kızılhaç'ta çalışarak ve 1921'de Hindistan'da bir mihracenin yanında özel sekreter olarak görev yaparak, İngiliz İmparatorluğunun resmi sıfatlarını taşımıştır. Eserlerinde öne çıkan hümanist düşünceleri yanı sıra 1912-1913 ve 1921'de iki kere yolculuk yapıp bir sürede yaşadığı Hindistan'da İngiliz imparatorluğuna, İmparatorluk görevlileri ve Hintlilerin ilişkilerine, Hindistan'ın bağımsızlık mücadelesine ve sınıf farklılıklarına dair gözlemleri ve düşünceleri romanlarında önemli yer tutar.

Ömer Seyfettin, Ashab-ı Kehfimiz (1918) adlı uzun hikâyesinde, Dikran Hayikyan adlı bir Ermeni gencinin bakış açısıyla, II. Meşrutiyet Döneminde ve Balkan Savaşları devam ederken kurulan ve ortak dil, ortak din ve ortak ülkü amaçlı bazı çalışmalar yapan Osmanlı Kaynaşma Kulübü ekseninde, Osmanlılık, imparatorluk, Türklük kavramlarını araştırır. Ashab-Kehf, Hz. Muhammet ve Hz. İsa arasındaki dönemde yaşayan Hristiyan yedi gencin ve bir köpeğin toplam 309 yll bir mağarada uyuyakalmasını anlatan hikâyedir (Çelik, 2017, s. 194-195). Ömer Seyfettin'in eserine ilham vermesinin sebebi ise eserin sonunda "Türk milletindeki 'Türklük' bilincinin uyanması ve 'milliyet'e dair bir farkındalığın oluşmasının, Ashâb-ı Kehf'in uykusundan uyanmasına" benzetilmesi yani "Türk milletinin 'milliyet/Türklük' bilincinden uzak oluşu, Ashâb-ı Kehfin uykuda yüzyllar geçirmesi olarak” düşünülmesidir (Erdem ve Demir, 2019, s. 121). Hatta Baytimur (2015) Ömer Seyfettin’i "toplumu uykudan uyandırma görevini üstlenen bir kültür isçisi misyonunu yüklenmiş ve pek çok 
edebî türde yazarak büyük bir mücadeleye girişmiş” bir yazar olarak tanımlayarak Ashab-ı Kehf ile bağdaştırır (s. 179).

Öte yandan E. M. Forster'un aslında büyük ölçüde 1913'de bitirdiği A Passage to India romanı 1924'de yayınlanmış ve roman Türkçeye hem Hindistan'a Bir Geçit hem Marabar'a Yolculuk adlarıyla çevrilmiştir. A Passage to India romanının başlı̆̆ Amerikalı şair Walt Whitman'ın Çimen Yaprakları (Leaves of Grass) şiir kitabının 'Passage to India' başlıklı şiirinden alınmıştır. Romanda, 1947'ye kadar İngiliz İmparatorluğunun bir sömürgesi olan ve henüz Hindistan, Pakistan ve Bangladeş olarak bölünmemiş altkıtadaki hayâli Çandapur şehrindeki İngiliz İmparatorluk görevlileri ve yerel halk arasındaki ilişkiler ve İngiliz sömürgesi olan Hindistan'da ivme kazanan İngiliz karşıtlı̆̆ı sergilenir. Aslında Kuchta'nın da (2003) altını çizdiği gibi bu romanda Forster, İngiliz İmparatorluğunun Hindistan'dan niçin çekilmesi gerektiğini anlatır (s. 308). Müslüman bir Hintli doktor olan Aziz’in Çandapur'a şehir hâkimi ile nişanlanmak amacıyla gelen Adela Quested adlı İngiliz bir kadını taciz ettiği yolundaki asılsız suçlamalar eksenindeki olayların anlatıldığı romanda, sadece İngilizlerin girebildiği İngiliz-Hint Kulübü ve bu kulübün İngiliz sömürge idarecilerinin hayatındaki yeri de önem kazanır.

\section{Emperyalizm ve sömürgecilik}

Çok milletli, çok kültürlü, çok dilli ve çok dinli devletler olan Osmanlı İmparatorluğunun ve İngiliz İmparatorluğunun coğrafi, sosyal, kültürel, etnik, dilsel ve dini farklllıkları nedeniyle bu iki eseri karşılaştırabilmek ve benzerliklerini ortaya koyabilmek için emperyalizm ve sömürgecilik kavramlarını tanımlamak, Osmanlı İmparatorluğunun ve İngiliz İmparatorluğunun bu tanımlara ne kadar uyduğunu araştırmak ve böylelikle bu eserlere hâkim olan havayı ve yazarların bakışlarını anlamak gerekir. Bazı yazarlar imparatorluğun ve sömürgeciliğin eş anlamlı olarak kullanıldığını söylemektedir (McLeod, 2000; Loomba, 1998). Ancak sömürgeciliğin emperyalizmden en önemli farkının özellikle Avrupalı bir milletin başka bir milletin/topluluğun topraklarını ya da sahipsiz toprakları işgal etmesi ve yerleşmesi olduğu, emperyalizmin ise daha ziyade bu işgali meşru çıarmak ideolojisi olduğu (McLeod, 2000), bir devletin bir başka ülke toprağındaki otoritesi olduğu (Boehmer, 1995) ve metropolitan bir merkezin uzak bir diyardaki uygulamaları, teorisi ile tutum ve davranışları olduğu (Said, 1993) belirtilir.

Osmanlı Devleti özellikle 15. yüzyıldan itibaren üç kıtada toprakları olan büyük bir imparatorluk olarak elbette ki bu tanımlara uygun olarak fethettiği yerlerde otoritesini kurmuş ve yönetim kademelerini oluşturmuştur. Öte yandan İngiltere özellikle 12. yüzyılda başlayıp 18. yüzyılda tamamlanan süreçte Birleşik Krallık olarak üniter yapısını tamamladıktan sonra 20. yüzyılın başında beş kıtada toprakları ve sömürgeleri olan bir imparatorluğa dönüşmüştür. Her ne kadar iki devletin de büyümesinde güçlü orduları, güçlü donanmaları ve savaşları finanse edecek güçlü ekonomik yapıları etkili olsa da Birleşik Krallı̆̆ farklı kılan Portekiz, İspanya, Hollanda, Fransa ve Belçika gibi ülkelerle birlikte coğrafi keşifler, yeni silahlar ve teknolojik gelişmeler sayesinde köle ticaretinden, deniz aşırı ticaretten ve sömürgelerinden elde ettiği muazzam gelirler olmuştur. Hindistan özelinde ise İngiltere'nin 17. yüzyılın başında 'East India Company’ ile ülke üzerinde kurduğu baskı, zamanla tüm kıtada ekonomik, ticari, eğitim, askeri, yönetim ve hukuk sistemlerinin tamamen Birleşik Krallık çıkarlarına göre düzenlenmesine yol açmıştır. Her ne kadar Hindistan'da 1857'de İngiliz sömürge idaresine karşı patlayan ilk isyan kanlı bir şekilde bastırılmış olsa da bağımsızlık ve milliyetçilik hareketleri gittikçe ivme kazanmaya başlamıştır. A Passage to India'da Hindistan'da 1885'de kurulan Hint Ulusal 
Kongresi ile başlayan ve Gandi’nin 1915'de başlayan ve 1920lerden sonra güçlenen bağımsızlık mücadelesine dair ipuçları doğrudan bahsedilmese de metinde görülmektedir (Bhaduri, 2018).

Osmanlı İmparatorluğu, 1683'deki II. Viyana Kuşatmasından sonraki süreçte 1699'da Karlofça Anlaşması ile toprak kayıplarına başlamış ve 20. yüzyılın ilk çeyreğinde Osmanlı İmparatorluğu emperyalist gücünü kaybetmiş ve dağılmanın eşiğine gelmişken İngiliz İmparatorluğu halâ dünyanın her yerindeki sömürgeleriyle toprak büyüklüğü ve nüfus olarak dünyanın en büyük devleti olarak en güçlü döneminde idi. 1947'de Hindistan'ın ikiye ayrılarak da olsa İngiliz İmparatorluğundan ayrılması ile sonlanan sürece tanıklık eden Forster'ın romanına benzer şekilde Osmanlı İmparatorluğunda yükselen milliyetçi ve ayrılıkçı hareketler ile 1908'de ilan edilen II. Meşrutiyet ve 1912-1913 Balkan Savaşları doğrudan Ömer Seyfettin'in Ashab-Kehfimiz adlı uzun hikâyesine yansır. Dolayısıyla iki yazarın bu eserlerinin en önemli benzerliği imparatorluk topraklarında ivme kazanan milliyetçilik hareketlerine ve imparatorluğun son zamanlarındaki siyasi gelişmelere ve reformlara tanıklık etmeleri ve imparatorluk tebaası ve imparatorluğun kurucu unsurları arasındaki ilişkilere dair gözlem, duygu ve düşüncelerini eserlerine yansitmalarıdır.

\section{Ötekiler ve milli kimlik}

Bu bağlamda her iki eserde de hem karakterlerin değişiminde hem olayların gelişiminde milli kimlik ve ülkedeki 'öteki’ olarak ortaya çıkan kişilerle ilişkiler önem kazanır çünkü Şen-Sönmez'in (2017) belirttiği gibi "milliyetçilik kimliği ağırlıklı olarak 'öteki’nin üzerinden tanımlanır" (s.675). "Çoğu zaman ileri sürülen kimlik hasımlık üzerine - ters yönde - inşa edilir" diyen Maalouf da (2005) "bir kişinin belli bir gruba ait oluşunu belirleyen şeyin temelde başkası olduğunu" belirtir (s. 19, 26). Özellikle sömürgelerde yaşayan herkes bir şekilde 'öteki' olduğu için (Loomba, 1998, p. 52), karşıllklı ilişkilerde kimin hâkim kimin 'öteki' olacağı aynı imparatorluk topraklarında yaşayanların ekonomik, sosyal ve dilsel üstünlüğü ile belirlenir. Ulu’ya (2007) göre "kimliğin anti tezi olan 'öteki', 'ben/biz' olmayan, istenmeyen, ötelenendir. 'Öteki', bu çerçevede, 'biz' tarafının bittiği yerde başlar; 'biz’in dış sınırıdır ... 'ben/biz' kimliğini değiştiren/ dönüştüren yapıcı bir unsurdur. Öteki bu tutumuyla hem kendini konumlandırır hem de berikini inşa eder" (s. 302).

Osmanlı İmparatorluğu, 15. yüzyıldan itibaren üç kıtada elde ettiği topraklarını ve yaklaşı 600 yıl süren büyük gücünü $A s h a b-\imath$ Kehfimiz'in olay örgüsünün cereyan ettiği 20. yüzyılın başına gelindiğinde büyük ölçüde kaybetmiştir. Solak’ın (2009) belirttiği gibi “Türkler, oldukça geniş bir coğrafyaya yayılmış olan Osmanlı İmparatorluğu'nun aslî unsuru olmalarına rağmen, yönetici elite asgarî oranda katılmışlar; hatta asırlarca süregelen devlet politikaları neticesinde unutulmuş bir unsur olarak kalmışlardır" (s. 422). Hatta "İstanbullu Müslüman/Türkler, kendilerinin dışındakilere -Türk olsalar bile- "öteki” olarak ifade edebileceğimiz bir dışlayıcılıkla yaklaşırlar" (Solak, 2009, s. 424). Ashab-ı Kehfimiz'de de Osmanlı İmparatorluğunun hâkimiyeti altında yaşayan diğer milletlerinin ve dinlerin mensupları 'öteki' değil bizzat bu devletin kurucusu olan ve kendilerinin dilleri ve kültürleri hem bazı soydaşları hem diğer milletlere mensuplar tarafından küçük görülen ve bu anlamda kurucusu olduğu devlet içinde ‘öteki’ konumunda olan ve dilleri ve mili kimlikleri hor görülen Türklerdir.

Ashab-ı Kehfimiz, Hayikyan'ın günlüğüdür ve Hayikyan kendi düşüncelerini ve kulübün kurulma sürecini anlatırken önce II. Meşrutiyet’in ilanının sonra da Balkan Savaşlarının İstanbul'a nasıl yansıdığını da kendi açısından aktarır. Böylelikle dönemin siyasi gelişmeleri ve savaşların milliyetçilik duygularını nasıl değiştirdiğini ve geliştirdiğini anlamak mümkün olur. Şen-Sönmez’in de (2017) değindiği gibi imparatorlukların tarihe karışmalarının en önemli sebeplerinden birisi milliyetçilik 
hareketleri olduğu için, Ömer Seyfettin hikâyesinde bu konuyu ön plana çıarır ve hikâyede "Osmanlıcılığı savunanlar ve millı̂ kimliği yok sayanlar ironik bir üslupla hicvedilirken 31 Mart ayaklanması sırasında millet kavramı yerine ümmet kavramını koyanlar cehaletleri ile eleştirilir” (s. 675, 681). Aslında bu eserde o yıllarda Osmanlı aydınları arasında süregelen ve "Tanzimat dönemi ve sonrasında Osmanlı toplumunun Batı karşısında geri kalmışlık sorununa çare olarak düşünülen” 'Batıcılık', 'Osmanlıcılık', 'İslamcılık' ve 'Türkçülük' tartışmalarının yansımaları görülmektedir (Taş \& Göksüçukur, 2019, s. 467). Abdullah Cevdet, Celal Nuri İleri, Ahmet Rıza Bey ve Kılıçzade Hakkı Bey’in düşünceleriyle etkilediği Batıcılar, dini kişisel alana indirerek tamamen Batılılışmayı savunmakta idiler. Gerçek İslam'a ve ‘Asr-ı Saadet'e' dönmeyi ve arınmayı savunan İslamcılar arasında Muhammed Abduh ve Mehmet Akif ön plana çıkmaktaydı. Hüseyinzade Ali, İsmail Gaspıralı, Yusuf Akçura, Ziya Gökalp gibi isimler ise ulus-devlet modeli ile dilde sadeleşmeyi savunmaktaydı (Taş \& Göksüçukur, 2019, s. 474-485). Ömer Seyfettin, özellikle dil konusundaki düşünceleri ve İstanbul Türkçesinin kullanılması yolundaki tavsiyesi nedeniyle Türkçü kanada yakındır. Osmanlı Devleti ile Türk Milletini birbirinden ayıran Seyfettin (1914), Osmanlıca diye bir lisanı kabul etmediği gibi Osmanlı adında bir milletin de olmadığını söyler. Ömer Seyfettin'e (1914) göre bu ayırımı yapmayanların amacı Türk milletinin varlı̆̆ını reddetmektir.

Hikâye, 30 Ağustos 1918'de Moda'da başlasa da olay örgüsü 10 yll geriye gider. Hayikyan, II. Abdülhamit'in devrilip Selanik'e sürgüne gönderilmesinden sonra İstanbul'a hâkim olan havayı anlatarak başlar. Babası bir Ermeni komitacı olan Hayikyan, 23 Temmuz 1908'de ilan edilen II. Meşrutiyet'in, iki ay öncesine kadar hasta adam olarak nitelenen Osmanlı'nın artık iyi olmayacağına inandığı için Ermenistan'a özerklik verilmesinin ve Kürtlerle Türkleri Ermenileştirmenin uygun olacağı düşüncesindedir. Artık düşüncelerinin değiştiğini ve tüm Osmanlı milletlerinin kalbinin "Hür Osmanlılık” için çarptığına, tüm bu milletlerin Amerika gibi bir arada mesut yaşayabileceklerini inandığını söyleyerek "Osmanlıyım. Osmanlı kalacağım” demektedir (Seyfettin, 2017a, s. 62). Özellikle iktisadi anlamda birliğin önemli olduğuna inanmakta olan Hayikyan, bu düşüncelerinin geneli yansıtmadığını ve Osmanlılık düşüncesine diğer milletlere mensup kişilerin karşı çıtığını ve milliyetlerinden vazgeçmek pahasına Osmanlı milletine sahip çıkanların sadece Türkler olduğunu fark eder. Türk millî kimliğini bazı Türkler kabul etmeyip daha kucaklayıcı olduğunu düşündükleri Osmanlı aidiyetini ön plana çıkarmaya çalışmaktadır. Aslında 31 Mart Vakasına, Derviş Vahdeti ile bazı isyancıların asılmalarına şahitlik eden Hayikyan, Ermeni bir gazeteci kimliğiyle isyan zamanı görüştüğü bir çavuşun Türklüğünü kabul etmeyip kendini Müslüman olarak tanımladığını hatırlar. Pek çok Türkün kendi milliyetlerini inkâr ettiğini, idealleri olmadığını düşünür. Türk olduğu halde kendini Türk olarak tanımlamayan Çavuş aslında kendini aydın olarak tanımlayanlardan millî kimlik ve bilinç anlamında farklı değildir. Demir’in de (2007) altını çizdiği gibi diğer milletlerden olanların büyük çoğunluğunun aslında Osmanlı bağlılığı olmadığı gibi tam tersi kendi milliyetçi gayeleri doğrultusunda "kendilerine ait olduklarını varsaydıkları mekânları elde etme[ye]" çalışmakta "bu durum, bireylerdeki Türk kimlik algısına zarar veren, bunu geciktiren bir kabul” olarak ortaya çıkmaktadır (s. 205-206).

Ömer Seyfettin, 'Osmanlı Milleti' hayali kuran bir başka karakter olan Muslihiddin Efendiye, ayrı bir hikâye gibi yazılmasına rağmen aslında Ashab-ı Kehfimiz’in bir bölümü olan Tatlısu Frenkleri başlıklı hikâyede yer verir. O da tıpkı Hayikyan gibi "kaynaşmış, imtizaç etmiş, tıpkı Amerikalılar gibi ayrısız gayrısız bir millet yapmak" istemektedir ve "Osmanlılık gayesini, bu insanî ve umumî ideali tebellür ettirmek" amacındadır (2017b, s. 125). Şimeler isimli hikâyesinde de Ömer Seyfettin, 'gayet büyük bir adam' olarak alay ettiği karakterin Türkiye, Türk ve Turan kelimelerine gösterdiği tepkiyi ve kendisini Osmanlı olarak tanımlamasını eleştirir. Türklük bilinci olmayan ve milli kimliğini inkâr eden bu kişi 
'Mağşûşü'l-milliye' olarak kabul ettiği Türk-Osmanlı nüfusuna "millî ve dinî bir mefkûre vermek insanlığa karşı bir hıyanetti” diyerek milli kimliği reddeder (2017c, s. 154). Piç adlı hikâyede ise "Frenk Nihat' denilen ve "Türklüğe dair ne varsa tahkir eder, Türkçe konuşmayacak kadar nefreti[n]de taassup" gösteren bir karakter çizer (2017d, s. 237).

Hayikyan, zamanın aydınlarından olarak değerlendirilen Niyazi Bey ile tanıştığında, Osmanlının bütün etnik unsurları birleştirip kaynaştıracak bir Osmanlı milleti oluşturma yolunda çalışacak Osmanlı Kaynaşma Kulübü kurmaya çalıştıklarını öğrenir. Hayikyan önce tereddüt etse de kulüp kurucusu Türklerin kendi kimliklerini, dillerini ve aidiyetlerini reddettiğini görünce, amacı yeni bir Osmanlı Milleti kurmak olan ve Temmuz 1909'da faaliyetlerine başlayan Kulübe katılır. Kulübün idare heyetinde bulunan az sayıda Türk'ün yanında isimleri Salihü’l-ayni Efendi, Nikefor Koştanof Efendi, Nikolaviç Efendi, Mina Efendi, Moiz Bori Efendi, Diyamandis, Hayikyan, Câsimü’l-Kürdî, Louis Durant Bey olan, Yahudi, Levanten, Rum, Ermeni, Arnavut, Arap, Romen ve Sirp üyeler bulunmaktadır. Bu kulübün amacı her milletten Osmanlı'nın katılımıyla millî hislerin kaybolması, yeni bir vatan kavramının meydana getirilmesi, herkese ortak bir lisan öğretilmesi, tarihsiz ve dinlerinden kopmuş bir milliyetin oluşturulmasıdır. Ortak dil olarak Esparanto, İbranice ve Latince önerilir ama Rum Diyamandis buna karşı çıkar. Hayikyan, Volapük ve İdo (Ydo) lisanslarını örnek vererek yapay dillerin tutmayacağını bunların yerine çok kolay bir dil olan Ermenicenin ortak dil olarak kullanılmasını önerince Türk üyeler karşı çıkmak yerine Türkçeden vazgeçmeye hazır bir tavır sergilerler. Öte yandan, Türk üyelerden biri dinin de ayrıştırıcı olduğu savıyla Osmanlı milletinin tek bir dini olması gerektiğini, bu dinin İslamlığın, Museviliğin, İseviliğin, Saibîliğin dışında başka bir olan Din-i İbrahimi olmasını önerir. Yine Türk üyeler, Osmanlıları kaynaştırmak için ilk yapılacak işin "bilâ-tefrik-i cins ü mezhep" kız alıp kız verme olacağını iddia ederler. Bu kulüp aynı zamanda gazeteler ve kitapçılar yayınlayarak, konferanslar düzenleyerek ve şubeler açarak "Milletim nev-i beşerdir, vatanım ruy-i zemin' ilkesini gerçekleştirmeye çalışacaktır. Türkler diğer Osmanlı'nın diğer milletlerine karşı bir ayrımcılık ya da diğerlerini 'ötekileştirmedikleri’ gibi kendi dillerinden ve dinlerinden vazgeçmeye hazır görünürler.

Mayıs 1910 ortalarında iki yıllı̆̆ına Marsilya'ya giden Hayikyan, 22 Nisan 1912'de döndükten sonra kulübe uğradığında kendisi yokken yirmi kadar toplantı yapıldığını ama hiçbir sonuç alınamadığını öğrenir. Zaten kendisi ve yedi Türk üye hariç toplantılara gelen de kalmamıştır. Kulübün Türk üyeleri bu kulübün amaçlarını gerçekleştirme düşüncesine kendilerini o kadar kaptırmışlardır ki ne Rumların “İstanbul'u, İzmir'i falan zapt edip bu on dört milyon [Türkü] 'Kızılırmak'ın să̆ tarafına atmak; Ermenilerin fikri, Büyük Ermenistan'ı teşkil edip, ne kadar Türk varsa hepsini 'Kızılırmak'ın sol tarafına atmak" olduğunu anlayamamışlardır (Seyfettin, 2017a, s. 91). Bu kulübün Türk üyeleri gerçeklerden o kadar kopuktur ki üyelerden Hoca Bali Efendi İstanbul'daki Azerbaycan Türklerini Acem sanmaktadır. Ekim 1912'de başlayan Balkan Savaşından kulüp üyelerinin haberi bile olmaz, kısır tartışmalarına devam ederler. Kulüp üyeleri kendi dünyalarına o kadar dalmışlardır ki "Asker sevkiyatına hiç bakmıyorlar, hatta o kadar gürültüleri işitmiyorlardı bile...” (Seyfettin, 2017a, s. 94). Hâlbuki Balkan Savaşı devam ederken azınlıkların Osmanlı'nın yenilgisine hazırlandıkları ve bu durumdan gayet mutlu oldukları açıtır. Bulgarlar Kral Ferdinand'ın Ayasofya'da taç giyme törenini hayal ederken, Rumlar 'İstanbul'un asıl sahibi' dedikleri Konstantin'i beklemektedirler. Bu durumu bilen Hayikyan'a göre Türklerin ancak büyük bir mağlubiyetle kendilerine gelebilecekler ve milliyetçilik hisleri uyanırsa da diğerlerinin sonu pek hoş olmayacaktır.

A Passage to India'ya konu olan olaylar da aynı zaman dilimine denk gelir. Ancak artık dağılma döneminde olan Osmanlı İmparatorluğunun aksine İngiliz İmparatorluğu bütün kıtalarda işgal ettiği 
toprakları ile devasa sınırlara ulaşmış ve bu yüzden de topraklarında gerçekten güneş batmayan bir devlet haline gelmiştir. Aslında koca kıtada sayısı 1000 civarında olan İngiliz imparatorluk görevlisi (Ferguson, 2003, s. xvi), romanda söz edildiği gibi saylları yaklaşık 170 milyon nüfuslu Hindistan'ın yönetimini, adalet, güvenlik ve eğitim sistemlerini ve ticaretini idare etmektedir. Ancak tipik bir sömürgeci devlet olarak, kendilerinin sahip olduğunu varsaydıkları üstünlüğünü, vahşi, kötü, geri kalmış, gelişmemiş gibi sıfatlarla etiketledikleri sömürgelerinin kendilerinden aşağıda olduğu varsayımına dayandırdıkları için kendilerini evrenin merkezi olarak görmekte ve sömürge halkını 'öteki’ olarak hakir görmektedirler (Tyson, 2006, s. 419). Poyraz ve Arıkan da (2003) 'ötekileştirmenin' karşıtlık ile yapılageldiğini "böylece Avrupa ötekinin vahşi/ yamyam olduğunu vurgulayarak kendisini uygar olarak tanımlamaktadır” demektedir (s. 68).

Forster'ın romanı üç Hintlinin "İngilizler ile arkadaş olmak mümkün mü?” sorusuna cevap arayışı ile başlar ve Christensen'in (2006) saptadığı gibi “Ingilizlerin sömürgecilik uygulamalarının radikal bir eleştirisine" dönüşür (s. 158). Hindistan dil, din, etnisite, yemek tercihleri, gelenekler ve yaşam biçimi açısından çok büyük farklılıklara mekân olan bir ülke olmasına ve bu topluluklar arasındaki çatışmalar ve çekişmeler de romanda yer alsa da esas sorun sömürgeci İngilizler ve yerli halk arasında yaşanmaktadır. Romanda da her etnik kökenden ve dinden Hintli, kendi ülkelerinde 'öteki' oldukları için İngiliz İmparatorluğunun kurucusu ve hâkimi olan İngilizlerin ırkçllğa varan ayrımcılı̆̆ından ve sömürgeci idaresinin uygulamalarından mustariptir. Romanda İngilizlerin Hintliler ile ilişkisini betimleyen birinci unsur Hindistan'da bulunan İngilizlerin Hintliler araya koydukları fiziksel ve sosyal mesafe ile tepeden bakıcı ve ayırımcı tavırlardır. Evleri bile şehirdeki diğer evlerden ayrı bir yerde tepenin üzerindedir ve şehrin geri kalanı ile tek ortak noktası gökyüzüdür (Forster, 1984, s. 2).

İngilizler ile Hintlilerin ilişkilerinde en belirgin özellik, İngilizlerin Hindistan'a geldikten sonra sömürgeci ve egemen olduklarını idrak edip Hintlilere de bu durumu hatırlatmaya ve ötekileştirmeye başlamalarıdır. Hamidullah, İngiltere'de iken kendisine çok iyi davranan ailenin birlikte büyüdüğü çocuğu Hindistan'da başka bir şehirde görev yapmaya başlar ama Hamidullah yanlış anlaşılma endişesi ile arkadaşını aramaktan çekinir. İngiliz erkeklerinin olumsuz anlamda değişmesi en fazla iki yıl alırken İngiliz kadınlarının olumsuz tavırlar takınması altı ayı bile bulmamaktadır. Özellikle şehrin Sağlık Müdürü olarak nitelendirilebilecek ve aynı zamanda doktor olan Binbaşı Callendar, polis müdürü McBryde, hâkim Ronny Heaslop ve şehir valisinin karısı Mrs. Turton, Hintlilere karşı ırkçı, ayrımcı, ötekileştirici davranış ve tavırları ile ön plana çıkarlar. "Örnek bir emperyalist" olan Ronny, Hintlilerle tek bağının astlarıyla resmi işleri olduğunu, başka şekilde onlarla ilişkisi olamayacağını söylerken bir yandan da Hintliler için yaptıklarının "değerinin bilinmediğine inanır" (Christensen, 2006, s. 167). Kuchta'nın da (2003) işaret ettiği gibi 'Köprü Partisinde' Vali’nin eşine Hintli kadınları göstererek 'hadi işe' demesi de İngilizlerin Hintlilere bakış açısını gösteren bir örnektir (s. 313). Hintlileri eleştirmek, aşağılamak ve ötekileştirmek için hiçbir fırsatı kaçırmayan Ronny, Aziz’in gayet iyi niyetle kendi gömlek yakasını Fielding'e verdiğini bilmeden, Aziz’in sarkan yakasını görünce bunu Hintli ırkının detaya önem vermemesi ve gevşekliği olarak yorumlar (Forster, 1984, s. 75). Ronny'nin yirmi beş ylllk görev süresince öğrendiği en önemli hususlardan birisi, "Hintlilerle resmi ilişki kurulabileceği, nezaket gösterilebileceği ama hep felaketle sonuçlandığı için asla samimi olunmaması" gerekliliğidir (Forster, 1984, s. 158). Aziz'in özel hayatı olabileceğini hiç düşünmeden yerli yersiz çağıran Callendar da, Ronny gibi astlarına hiç güvenmez ve koyu tenli ırkların açık tenlilere karşı bir ilgisi olduğu yolundaki varsayımını mahkemede Aziz'in suçluluğuna kanıt olarak seslendirir (Forster, 1984, s. 212). Öte yandan Polis Müdürü McBryde ise, kendisi de Karaçi doğumlu olduğu halde 30. Enlemin güneyinde yaşayanların tamamımın doğuştan suça eğimli oldukları yolunda bir kanaate sahiptir (Forster, 1984, s. 160-161). Mrs. Turton ise mahkeme süresince Hintlilere duyduğu yoğun 
nefreti dile getirirken bu gibilerin Marabar Mağaralarına kadar sürüne sürüne gitmelerini ve yol boyunca onlara herkesin tükürmesinin gerektiğini söyler (Forster, 1984, s. 210).

Okul müdürü Cyril Fielding ise tamamen hümanist düşüncelere sahip olduğu için sürekli kendi çevresinde eleştirilme pahasına Hintlilere uzak durmamaktadır. Vali'nin düzenlediği 'Köprü Partisinde' Hintlilerle sohbet eden ve onlara dostluk gösteren, hasta olduğunda Azizi evinde ziyaret eden, Aziz’i evine çaya davet eden, Aziz'in masumiyetine inanıp İngilizlere karşı onu savunan tek kişi Fielding olur. Hintlilere tavir göstermeyen ve onlara nezaket gösteren diğer iki karakter olan Mrs. Moore ve Adela Quested ülkeye yeni geldikleri için henüz vatandaşlarının kaba, tepeden bakan ve ötekileştirici tavır ve hareketlerini tekrar etmemektedirler. Mrs. Moore camide Aziz'e rastlayınca son derece kibar davrandığı için Aziz onun yeni geldiğini tahmin eder. Aslında Mrs. Moore'un Hindistan'da mutsuz olmasının önemli sebebi de "diğerlerine vermekten, diğerlerini anlamaktan, diğerlerini anlamaya çalışmaktan ve esas görevinin ötekilere yardım etmek olmasını düşünmesinden dolayı bitap düşmesidir" (Melfi, 2019, s. 121). Adela, sürekli "gerçek Hindistan'ı" görmek istediği ve zaman zaman Hintlilerle kısa da olsa görüşmekten kaçınmadı̆̆ i i̧in 'yerlilerin' samimi olduktan sonra kendilerine saygı duymadığını düşünen diğer İngiliz hanımlarının eleştiri oklarının hedefi olur (Forster, 1984, s. 21). Mrs. Moore cami ziyaretinden ve orada bir doktorla tanışmasından söz edince "sesinin tonuyla bir Hintliden bahsettiğini ima etmediği” için oğlu Ronny, İngiliz bir doktordan söz ettiğini sanır ve bu nedenle uzun uzun Aziz’in annesine nasıl hitap ettiğini, bir saygısızlık yapıp yapmadığını sorgular (Forster, 1984, s. 23-24).

Milletlerarası evliliği savunan Osmanlı Kulübü üyelerinin aksine, Çandapur'daki İngilizlerin Hintliler ile evlilik yapması ihtimali bile yoktur. Fielding’in gayet iyi bildiği gibi Hintlilerle dostluk eden çok az sayıda İngiliz’in İngiliz kadınlar ile ilişki kurma şansı kalmaz. Bir İngiliz kadının Hintli bir erkek ile evlenmesi hiç kabul edilebilir bir durum olmadığı gibi bir İngiliz kadının iki Hintli ile aynı yerde bulunması bile sorun olmaktadır. Adela Quested'ın taciz edildiği iddiasının büyütülmesinin en önemli sebebi ise taciz şüphelisinin Hintli bir Müslüman olan Aziz olmasıdır.

Osmanlı İmparatorluğunda yaşayan milletlere mensup kişilerin oluşturduğu Kaynaşma Kulübünün aksine Forster'ın romanında İngiliz-Hint Kulübüne üye olmak şöyle dursun Hintlilerin misafir olarak bile içeri girmesine bile izin verilmemektedir çünkü İngiliz-Hint kulübü hem alan olarak hem de irk açısından İngiliz-Hint topluluğunu ‘öteki” olarak ayıran bir habitat görevi görür (Crane, 2011, s. 19). İngiliz-Hint kulübünde İngilizler kendi alıştıkları yemekleri yiyip, polo, bilardo oynayıp, tiyatro oyunları sergiler. Hatta bu oyunlarda rol alanlar da kulüp üyeleri olduğu için itibarlarını korumak için Hintli uşakların bile bu temsilleri görmesine izin verilmez. Türklerin milliyetçiliğinin ayıplandığı Osmanlı Kulübünün tam tersine İngilizler bir temsilin sonunda İngiliz Milli Marşını büyük bir ciddiyet ve inançla hep beraber söyleyip İmparatorluk mensubu olmaktan duydukları gururu haykırırlar. Kulübe şehrin ileri gelen Hintlilerin bile girişi sadece şehir valisinin "Batı ve Doğuyu birleştirme" amacıyla düzenlediği ve son derece başarısız sonuçlanan 'Köprü Partisi' ile mümkün olur (Forster, 1984, s. 21). Ancak bu partinin amaçlandığı gibi köprü görevi görememesinin asıl sebebi öncelikle "çok zor, çok kişisel ve biraz da korkutucu bir iş olan bireylerin 'ötekiliklerini' kabul etmeleri, bilmeleri ve ortama dâhil etmeleri” gerektiğini bilmemeleridir (Melfi, 2019, s. 119).

\section{Uyanış}

Hem Ashab-ı Kehfimiz'de hem A Passage to India'da birbirinden farklı iki olay bardağı taşırır ve 'ötekilerin' yani kendi ülkelerinde çoğunluk olan Türklerin ve Hintlilerin Ashab-ı Kehf misali 
uyanmalarına ve isyan etmelerine neden olur. Maalouf un (2005) "zaten çoğu zaman kendinizi en fazla saldırıya uğrayan aidiyetinizle tanımlamaya eğilimlisinizdir” (s. 27) tespitindeki gibi milli kimliklerine, dillerine ve dinlerine yapılan saldırılardan, horlamalardan ve aşağılamalardan bıkan Türkler ve Hintliler nihayet isyan noktasına gelirler.

Ashab-ı Kehfimiz'de, kulüp üyeleri bir dergi çıarmaya karar verirler ve önerilen sekiz isim arasından kura çekince ‘İnsanlık' çıkar. Hayikyan'ın dergideki ilk yazısının başlı̆̆ " Memalik-i Osmaniye’de irken, cinsen bir tane olsun Türk Yoktur!” olur ve Anadolu'da Müslüman olsa da hiç Türk olmadığı gibi kendini Türk sananların da aslında Ermeni ya da Rum olduğunu iddia eder. Türk üyeler bu yazıdan en ufak bir rahatsızlık duymadıkları gibi tam tersi Dikran'ı kutlarlar. Ama bu yazılara tepkiler gecikmez ve Hayikyan'ın tahmini doğrultusunda Anadolu'nun pek çok yerinde galeyana gelen Türklerin ve 'Türk Yurdu”, “Türk Ocağı”, “Türk Gücü”, “Altın Ordu”, "Yeni Turan” ve "Türk Birliği” cemiyetlerinin şiddetli protesto telgrafları gelmeye başlar. Türk üyeler hiç önemsemeseler de Hayikyan bu telgrafları inceleyince "varlığı inkâr olunan büyük bir milletin bir tayfundan daha müthiş olan mukaddes, âlî hiddeti kabarıyor, taşıyordu" diye düşünür (Seyfettin, 2017a, s. 104). Büyük bir protesto gösterisi düzenlenir ve binlerce kişi katılır. Ateşli konuşmalardan sonra okul ve Darülfünun öğrencilerinin, adında Türk olan derneklerin ve meslek örgütlerinin atıldığı büyük bir geçit resmi düzenlenir. İz’an gazetesinde 'Ashab-ı Kehf' başlığıyla bu gösteriler anlatılır. Kaynaşma kulübünün üyelerini Ashab-ı Kehf olarak niteler ve mağaralarındaki uykularından nihayet uyandıklarını ve 'Yok!' dedikleri milletin binlerce evladı millî iştiyaklarını haykırarak mağaralarının önünden” geçince gördükleri manzara karşısında çok şaşırdıklarını yazar. Arapların, Ermenileri ve Rumların milli kimlikleri ve dinleri konusunda ne kadar tutucu oldukları ve İstanbul düşmek üzere iken bu insanların nasıl Osmanlı devletinin aleyhine çalıştıkları bilinmesine rağmen Osmanlıları kaynaştırma iddiası gütmenin ne kadar anlamsız olduğunun altı çizilir. Zaten bundan sonra Kaynaşma Kulübü dağılır hem Türk üyeler hem Türk olmayanlar kendi yollarına giderler.

Forster'ın romanında ise Hintlileri uyandıran ve harekete geçiren başka bir talihsiz olaydır. Aziz'in maddi ve manevi pek çok zorluğa katlanarak düzenlediği Marabar Mağaraları gezisi, başından itibaren yaşanan şanssızlıklar nedeniyle amacına hitap etmekten uzaklaşır ve Adela'nın mağaralardan birinde Aziz’in kendisini taciz etmekle suçlaması ile Aziz tutuklanır ve yargılanır. Her ne kadar mahkemede Adela suçlamasını geri çekse de bu durum şehir de tansiyonun artmasına neden olur. Zaten Muharrem ayı nedeniyle Müslümanlar ve Hindular arasında yaşanan sorunlar nedeniyle gergin olan şehir halkı Ashab-ı Kehfimiz'e benzer şekilde uyanır ve hem mahkeme esnasında hem Aziz'in beraat etmesinden sonra İngilizlere yoğun tepki göstermeye başlar. Hatta kalabalıkların kendilerine saldırabileceğini düşünen İngilizler kulüpte toplanırlar. Aziz de tüm iyi niyetine rağmen sürekli hor görülmekten bıkmışken bir de taciz suçlaması ile tutuklanıp yargılanınca İngilizlerle her türlü irtibatını kesmeye karar verir. İki yll sonra Fielding ile bir başka eyalette bir araya gelen Aziz artık Hindistan'ın bağımsızlığına inanan ve savunan ve tüm farklılıklara rağmen Hindistan'ın tek millet olacağını düşünen biri haline gelir. Aziz'e göre Hintlilerin tek yapması gereken Avrupa'da bir savaş daha çıııp İngilizler çekilene kadar beklemektir (Forster, 1984, s.315-316).

\section{Sonuç}

Görülmektedir ki birbirlerine çok yakın zamanda yazılan her iki eserde de çok uluslu, çok dilli, çok dinli ve çok kültürlü iki imparatorluğun 20. yüzyıl başındaki siyasal durumunun ve toplumsal olayların yansımalarını bulmak mümkündür. Her iki imparatorluk topraklarında da milletler arasındaki bir takım çekişmelerin, sorunların, isyanların ve hatta savaşların etkileri eserlerde izlenmektedir. Uzun 
yıllar Osmanlı İmparatorluğu idaresinde yaşamış Balkan devletleri, Osmanlı Devleti ile savaşta iken, Osmanlı Kaynaşma Kulübünün Türk olmayan Rum, Ermeni, Sırp, Arnavut ve Sırp üyeleri arasında da çekişmeler gözlenmekte, hatta Hayikyan Kürtlere nefretini dile getirmektedir. Aynı şekilde Forster'ın romanında Müslüman Hintlilerden Aziz ve Mr. Haq Hinduları kötülemekte, Müslümanlar ve Hindular arası çatışmalar romanda önemli yer tutmaktadır. Osmanlı Devleti bu yıllarda ekonomik ve siyasi sebeplerle dağılmanın eşine gelmiş iken İngiltere İmparatorluğu artan milliyetçilik hareketlerine rağmen hala pek çok sömürgesi ile varlığını sürdürmektedir. İki devlet arasında incelenen eserlere yansıyan en önemli fark, hâkir görülen ve ötekileştirilen milletlerdir. Ashab-ı Kehfimiz'de devletin kurucusu olmasına rağmen Türkler ve aidiyetleri, hem bazı Türkler tarafından hem diğer milletlere mensup kulüp üyeleri tarafından devletin başkentinde hor görülmektedir. A Passage to India'da ise İngiliz sömürge idaresi ve ailelerinin küçük gördüğü milletler aslında Hindistan'ın gerçek sahibi olan dil, din, kültür farkı olmadan tüm Hintlilerdir. Her iki eserde de sonunda ashab-ı kehf misali uyanan, isyan eden ve başkaldıran Türkler ve Hintliler olur. Milliyetçilik ve bağımsızlık fikirlerinin beslediği uyanıştan Türkler altı-yedi yıl sonra Türkiye Cumhuriyeti devletinin temelini atarken, Hindistan 1947’de iki parçaya bölünürken bağımsızlığını kazanır.

\section{Kaynakça}

Baytimur, N.M. (2015). Ömer Seyfettin'in şiirlerinde uluslaşma bilincinin yansımaları. KSÜ Sosyal Bilimler Dergisi, 12(1), 174-192.

Bhaduri, L.S. (2018). History and passage to India - A study. The Indian Review of World Literature in English, 14(1), 26-30.

Boehmer, E. (1995). Colonial and post-colonial literature: Migrant metaphors. Oxford: Oxford University Press.

Christensen, T. (2006, Spring). Bearing the white man's burden: Misrecognition and cultural difference in E.M. Forster's a passage to India. Novel, 1, 155-178.

Crane, R. (2011). Reading the club as colonial island in E.M. Forster's a passage to India and George Orwell's Burmese days. Island Studies Journal, 6(1), 17-28.

Çelik, H. (2017). Ashab-ı kehf kıssası ve içerdiği mesajlar. MANAS Sosyal Araştırmalar Dergisi, 6(1), 189-217.

Demir, A. (2007). Ömer Seyfettin'in hikâyelerinde millî kimlik inşa unsuru olarak mekân. Uluslararası Asya ve Kuzey Afrika Çalışmaları Kongresi ICANAS 38, 10-15 Eylül 2007, Ankara. 195-207.

Erdem, M., \& Demir, A. (2019). Metinsel-aşkınlık bakımından ashâb-ı kehf’in Türk dili ve edebiyatına yansımaları. Millî Folklor, 121, 16-29.

Ferguson, Niall. (2003). Empire: How Britain made the modern world. London: Penguin.

Forster, E.M. (1984). A passage to India. New York: A Harvest/HBJ Book. (İlk basım 1924).

Kuchta, T. (2003, Summer). Suburbia, ressentiment, and end of empire in a passage to India. Novel, $1,307-329$.

Loomba, A. (1998). Colonialism postcolonialism. London: Routledge.

Maalouf, A. (2005). Ölümcül kimlikler. (Çev. Aysel Bora). İstanbul: Yapı Kredi Yayınları (ìlk basım 1998).

Melfi, M.A. (2019, Spring). The solidity of the self: turning and returning in a passage to India. REN $71(2), 113-132$.

McLeod, J. (2000). Beginning postcolonialism. Manchester: Manchester University Press.

Poyraz, T., \& Arıkan, G. (2003). Avrupa-Türkiye ilişkileri ve dönemsel olarak değişen 'öteki’ tanımları. Hacettepe Üniversitesi Edebiyat Fakültesi Dergisi, 20(2), 61-71. 
Said, E. (1993). Culture and imperialism. London: Chatto \& Windus.

Seyfettin, Ö. (1914). Türkçe’ye kimler Osmanlıca der? Türk Sözü, 1(7). https://turkcetarih.com/tarihte-turkler/turk-dili-turkce/turkceye-kimler-osmanlica-der/

Seyfettin, Ö. (2017a). Ashab-ı kehfimiz. (Haz. N.H.Polat). Ötüken. (İlk basım 1918).

Seyfettin, Ö. (2017b). Tatlısu Frenkleri. Ashab-ı kehfimiz. (Haz. N.H.Polat). Ötüken. (İlk basım 1918). (s. 121-141).

Seyfettin, Ö. (2017c). Gayet büyük bir adam. Ashab-ı kehfimiz. (Haz. N.H.Polat). Ötüken. (İlk basım 1918). (s. 142-149).

Seyfettin, Ö. (2017d). Gayet büyük bir adam. Şimeler. Ashab-ı kehfimiz. (Haz. N.H.Polat). Ötüken. (İlk basim 1918). (s. 150-166).

Solak, Ö. (2009). II. Meşrutiyet romanında 'Türk' ve Türklük. Selçuk Üniversitesi Sosyal Bilimler Enstitüsü Dergisi, 21, 419-429.

Şen-Sönmez, Ü. (2017). Ashâb-ı kehfimiz adlı hikâyede II. Meşrutiyet devri fikir hareketlerinin yansimaları. International Journal of Languages' Education and Teaching, 5(1), 673-689.

Taş, K., \& Göksüçukur, B. (2019). Osmanlı dönemi batıcılık, İslamcılık, Türkçülük fikir akımları ve din. Dini Araştırmalar, 22(56), 463-488. DOI: 10.15745/da.583546

Tyson, L. (2006). Critical theory today. New York: Routledge.

Ulu, Y.S. (2019). Ömer Seyfettin'in öykülerinde devlet ve iktidar algısı. TÜRÜK Uluslararası Dil, Edebiyat ve Halkbilimi Araştırmaları Dergisi, 7(19), 291-305. 